\title{
INTEGRATION OF ISLAMIC EDUCATION VALUES TOWARDS THE "YATIMAN" TRADITION IN THE MONTH OF SURO IN PEKALONGAN
}

\author{
Laela Rohma Puji Lestari \\ Institut Agama Islam (IAIN) Pekalongan \\ laelarohmapuji@gmail.com \\ Sopiah \\ Institut Agama Islam (IAIN) Pekalongan \\ sopiah@iainpekalongan.ac.id \\ Hendri Hermawan Adinugraha \\ Institut Agama Islam (IAIN) Pekalongan \\ hendri.hermawan@iainpekalongan.ac.id
}

\begin{abstract}
Abstrak
Nilai-nilai pendidikan Islam adalah ciri khas, sifat yang melekat yang terdiri dari aturan dan cara pandang yang dianut oleh agam Islam. Dalam tradisi "yatiman" bulan Suro terdapat nilai-nilai pedidikan Islam yaitu dalam aqidah, syariah, dan akhlak. Sebagian masyarakat dalam melaksanakan Suroan sedikit telah bercampur dengan tindak budaya, dan bertentangan dengan Islam. Namun, berjalannya waktu masyarakat lebih memprioritaskan sesuatu sesuai ajaran Islam. Penelitian ini bertujuan untuk mendeskripsikan nilai-nilai pendidikan Islam dalam tradisi "yatiman" pada bulan Suro di Kelurahan Panjang Baru RW IX, Kota Pekalongan. Penelitian ini menggunakan pendekatan kualitatif dengan jenis penelitian lapangan. Adapun sumber data yang digunakan adalah berdasarkan hasil observasi, wawancara yang dilakukan bersama Lurah Panjang Baru, Ketua RW IX Kelurahan Panjang Baru, Ketua RT, Tokoh Agama Islam, Sesepuh Kelurahan Panjang Baru RW IX, dan Anak yatim, dan dokumentasi. Analisis data dalam penelitian ini menggunakan deskriptif kualitatif melalui reduksi data, penyajian data, dan penarikan kesimpulan. Hasil penelitian menunjukkan bahwa pelaksaan tradisi "yatiman" pada bulan Suro di Kelurahan Panjang Baru RW IX Pekalongan diawali dengan Tahlil, do'a bersama, dan kenduri malam Suroan kemudian dilanjutkan kegiatan tausiyah dan santunan anak yatim dikeesokan harinya. Nilai-nilai pendidikan Islam terdapat dalam nilai aqidah, nilai syariah, dan nilai akhlak.
\end{abstract}

Kata Kunci: Nilai-nilai Pendidikan Islam, Tradisi, “yatiman”, dan Bulan Suro.

\begin{abstract}
The values of Islamic education are a characteristic, inherent nature which consists of the rules and perspectives adhered to by the Islamic religion. In the "yatiman" tradition of the month of Suro there are Islamic educational values, namely in aqidah, sharia, and morals. Some people in implementing Suroan have mixed with
\end{abstract}


cultural acts, and are against Islam. However, as time goes on, people prioritize something according to Islamic teachings. This study aims to describe the values of Islamic education in the "yatiman" tradition in the month of Suro in Panjang Baru Village, RW IX, Pekalongan City. This study uses a qualitative approach to the type of field research. The data source used is based on the results of observations, interviews conducted with the Long Baru Village Head, the Head of RW IX, Panjang Baru Village, Head of RT, Islamic Religious Leaders, Elders of Panjang Baru Village RW IX, and Orphans, and documentation. Data analysis in this study used a qualitative descriptive through data reduction, data presentation, and conclusion drawing. The results showed that the implementation of the "yatiman" "tradition in the month of Suro in Panjang Baru RW IX Pekalongan began with Tahlil, prayer together, and the Suroan night feast then continued with tausiyah activities and donations for orphans the next day. The values of Islamic education are contained in the values of aqidah, sharia values, and moral values.

Keywords: Islamic Education Values, Tradition, “yatiman”, and the Month of Suro.

\section{Introduction}

Tradition is a hereditary custom (ancestral) which is still practiced by the community. In religious anthropology, rituals are also often referred to as ceremonies related to religious beliefs, occupying an important position in the existence and preservation of religion (Satibi, 2008, h. 61). Some Javanese Muslims have the Muharraman tradition which is carried out at the arrival of the month of Muharram, the first month in the Hijri calendar system, which Javanese usually call the suroan tradition (Solikhin, 2009, h. 11).

In the month of Suro, the Javanese Muslim community provides compensation to orphans (Suradi, Tabata, \& Surahman, 2020). Given the amount of reward given by Allah exceeds the other month (Muqoyyidin, 2016). Because supporting and loving orphaned children is an extraordinary practice in return for his kindness, but if he serves wrongly or scolds to hurt the orphans, the torment will be great because it is the same as denying religion (Yudha, 2016, h. 17).

The activity of providing orphanages in Kelurahan Panjang Baru RW IX Pekalongan is called the "yatiman" tradition. The "yatiman" tradition is carried out on 10 Muharram or Suroan which is still valid today. The "yatiman" tradition in Kelurahan Panjang Baru RW IX is different from the others, this tradition has its own charm for 
the actors involved in it, a series of events accompanying this tradition, including: tahlil, kenduri, taushiyah, and donations for orphans.

Based on some of the activities of the "yatiman" tradition, there are values of Islamic education, namely in aqidah, sharia, and morals (Yatiman, SM, \& Narti, 2019). However, some people in the month of Suro still believe in certain rituals which are sometimes judged by some religious leaders to be inconsistent with Islamic teachings (Wiediharto, Ruja, \& Purnomo, 2020). With practice, some people in Kelurahan Panjang Baru RW IX Pekalongan, especially the coastal areas, still carry out the traditional kenduri, which contains Islamic and pre-Islamic elements in the ritual. Coastal communities assume that this tradition was inherited by their previous ancestors. So the people in Kelurahan Panjang Baru RW IX have mixed a little with cultural acts (Sukron, 2020).

By looking at the phenomena above, it is not uncommon for those who know the values contained in the traditions they carry out (Abidin, 2019), it would be nice if when we have carried out this tradition we also know the values contained therein so that the hope of the community in preserving this tradition is only to believe in the existence of Allah SWT and carry out activities that contain Islamic educational values (Isdiana, 2017).

10 Muharram is an auspicious date, so this date holds a big event. Among them are, Prophet Yunus came out of the belly of a shark, Prophet Noah survived the flood, Prophet Moses split the Red Sea (Salman Irag Al-Najaf, Salehi, \& Nimr Al-Maliki, 2018). Because the month of Muharram saves major events, it is called Shuro and its amaliyah is called Suroan (Nur, 2016). Amaliyah carried out by several Muslim congregations related to Asyuro is, 2 days of fasting, on the 9th and $10^{\text {th }}$ (Janah, 2016). Followed by supporting some orphans with a procession of stroking the hair of orphans or commonly called Yatiman.

Based on the problem, it is clear that the implementation of the traditional "yatiman" activity in the month of Suro is not an activity that is against Islam, and of course contains the values of Islamic education as the example above. Therefore, this 
study aims to describe more deeply the values of Islamic education in the "yatiman" tradition in the month of Suro in Panjang Baru Village, RW IX, Pekalongan City.

\section{Research Methods}

The type of research conducted in this research is field research, which is research that aims to solve problems with the help of data in the field (Kartono, 1983, $\mathrm{h}$. 27). This means that there will be a direct study to Kelurahan Panjang Baru RW IX Pekalongan to obtain concrete data about the implementation of the yatiman tradition in the month of Suro that occurs in the area. Informants in this research are Lurah Panjang Baru, Head of RW IX, Kelurahan Panjang Baru, Head of RT, Islamic religious leaders, Elders of Kelurahan Panjang Baru RW IX, and orphans. They are 6 informants representing each element. This research has taken about 3 months.

Whereas in this study, the reserchers used a qualitative approach, namely data collection in a natural with the intention of interpreting the phenomena that occurred (Anggito, 2018, h. 8). By using a qualitative approach the researcher can describe systematically, actual or accurate facts related to the values of Islamic education in the yatiman tradition in the month of Suro in Panjang Baru Village, RW IX Pekalogan.

\section{Theoritical Review}

\section{Definition of Value}

The word value comes from the English language "value" including the field of philosophical studies. The term value in the field of philosophy is used to denote an abstract noun which means "worth or goodness, and a verb which means a certain psychological action in assessing or conducting judgments (Ahmad Jamalong, Sukino, 2019). In general, value is defined as the essence attached to something that is very meaningful to human life (Eakman, 2015). Especially regarding the goodness and goodness of a thing, to have value something must have characteristics or things that are important or useful to humanity.

According to Darmadi (2019), value is defined as something valuable, which is considered valuable, fair, good and beautiful and becomes a guideline or self-guidance. Value is also defined as a social goal or social goal that is deemed appropriate and 
valuable to achieve (Sholihah \& Maulida, 2020). The values referred to here are norms that apply in society. Value can also be a measure of good or bad things a person does.

Value is an abstract concept regarding basic issues that are very important and valuable in human life or a concept regarding the high respect given by the community to several main issues in religious life that are sacred in nature so that it becomes a guideline for the religious behavior of the community concerned (Martin \& Lembo, 2020). Therefore, value is defined as the quality of something that makes it likeable, desirable, usefull, valued, and can be an object of interest (Filson, 2018).

\section{Definition of Islamic Education}

Education is the transformation of knowledge, culture, as well as the values that develop in one generation so that it can be transformed into the next generation. In this sense education is not only a transformation of knowledge, but is already in the realm of cultural and value transformation that develops in society (Halik, 2020). In life, education is one of the most basic things that humans must do so that humans can survive this world and the hereafter (Ahmadi, 2020). In Arabic education is called tarbiyah which comes from the verb rabba, while teaching in Arabic is called the term ta `im which comes from the verb `allam (Suharto, 2018).

In Islam, education is very important and emphasized to its people. Yusuf alQardhawi said that Islamic education is the education of the whole human being, his mind and heart, spiritual and physical, morals and skills (Huda, 2015). Therefore, Islamic education prepares humans to live in a state of peace and war, and prepares them to face society with all its good and evil (Z. Lubis \& Anggraeni, 2019).

\section{Basic Values of Islamic Education}

The values of Islamic education are included in three basic frameworks, namely aqidah, sharia, and morals. The value of aqidah education is related to faith and piety, the value of sharia education is related to the truth and belief in laws, and the value of moral education is related to ethics and morals (Ufie, 2014).

First, The Value of Aqidah Education. Etymologically aqidah comes from the word 'aqada-ya'qidu-'aqidatan- 'aqdan which means conclusion, bond, agreement, and solid. Aqidah means a provision that does not doubt the person who makes the decision. 
Meanwhile, the meaning of aqidah in religion means that it relates to belief, not action (Purwati \& Devi, 2020).

Second, The Value of Shari'ah Education. Shari'ah are the rules of Allah that are used as references by humans in managing and regulating their lives both in relation to the relationship between humans and Allah, the relationship between humans and fellow humans, and the relationship between humans and the surrounding environment (Supriatna, 2019).

Third, Moral Education Value. Achmadi emphasized that the value of moral education is a very important educational content in Islamic education. Akhlak is the plural form of the word khuluqun which means character, temperament, behavior system that is made (S. A. Lubis, Neliwati, \& Ficki Padli Pardede, 2020). In morals includes the understanding of the creation of integration between the will of God and the behavior of creatures (humans). Or in other words, a person's behavior towards other people and their environment only contains real moral values if the action or behavior is based on the will of the God (Anam, Degeng, Murtadho, \& Kuswandi, 2019).

\section{Purpose of Islamic Education}

The goals of Islamic education are the goals that will be achieved by a person or group of people who carry out Islamic education (Susiyani, 2017). Educational goals are divided into two parts, namely general goals and specific goals, each of which is interrelated and functional (Quadir, Chen, \& Isaias, 2020).

The specific objectives of Islamic education are: Introducing students to the Islamic aqidah, the basics of religion, procedures for worshiping properly which are sourced from Islamic law; Cultivate the correct awareness of students about religion, including the principles and principles of noble morals; To instill faith in Allah the creator of nature, angels, messengers, and books; Fostering the interest of students to increase knowledge of manners, religious knowledge, and Islamic laws and efforts to practice them voluntarily; Instill a sense of love and respect for the Al-Qur'an (read, understand, and practice it); Fostering a sense of pride in the history of Islamic culture; Foster a sense of willingness, optimism, confidence and responsibility; and Educating 
the instincts, motivations and desires of the younger generation and fortifying them with faiths and values of politeness (Susanto, 2018).

The objectives of Islamic education focus on three dimensions, namely: 1) The formation of "insan kamil" (universal human, conscience) who has the faces of the Qur'an; 2) The creation of "insan kaffah" which has religious, cultural and scientific dimensions; and 3) Awareness of human functions as servants, khalifah of Allah as well as warasatul ambiya 'and provide adequate provisions in the context of carrying out these functions (Suraya, Hermawan, \& Pekalongan, 2020).

Based on the theories put forward by educational experts above, the concept can be taken that in essence the goal of Islamic education is to try to create an ideal human being in the image of Islam (Adinugraha, Hasan, Pekalongan, \& Semarang, 2020).

\section{Definition of Tradition}

Tradition is a community habit, both in the form of words and actions that are carried out continuously and as if it is a separate law (Frensch \& Funke, 1995), so that the soul feels calm in doing so because it is in line with reason and is accepted by a prosperous tabi'at. In the context of this tradition, each tradition of the Muslim community has a good traditional style, which differs from one society to another. Even though they have the same religion, in life as a nation and state they will form unique characteristics. With this assumption, there is a mention of universal Islam and local Islam. Opportunities with tradition can be used as a reference in the implementation of Islamic education (Sulaiman, Yusnaini, Jabaliah, Masrizal, \& Syabuddin, 2020). The acceptance of this tradition has several conditions, namely that it does not conflict with the main texts, both the Qur'an and the Sunnah, and the prevailing traditions are not against common sense and prosperous character, and do not show rebellion, corruption, and setbacks (Ayuningsih, Syafaruddin, \& MS, 2020).

\section{Understanding the Yatiman Tradition}

Orphan, the word "orphan" comes from Arabic, the plural form is yatama or aitam. This word includes the meaning of all children whose father has died, while "orphaned" is someone who does not have a mother anymore because he has died in the world when he has not reached the age of adulthood (adult), whether he is rich or poor, male or female, or Muslim or non-Muslim (Mahmuda, 2019). Orphans are entrusted to 
the people who must be given good support, taken care of, and educated, so that they can feel the same when their parents are still there.

The concern for orphans is often mentioned in the Qur'an, starting from the problems of the orphans themselves and the needs for the life of the orphans. In the Meccan period the attention of the orphans was more focused on caring for the orphans than on their possessions. As stated in the Al-Qur'an chapter Al-Fajr verse 17:

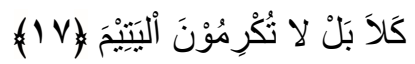

Meaning: "It is not so, in fact you do not glorify orphans". (Surah Al-Fajr: 17).

The orphan tradition is a charity activity for orphans, to be precise on the 10th, which is the Eid of the orphans. This tradition arises because there are indeed many hadiths that are known by most people, fadhilah supports orphans on the 10th of Muharram (Yatiman et al., 2019). Muharram is a glorious month, a holy month, and a month that is guarded, so that in that month, humans are ordered to increase their worship. Tradition generally appears with a social, economic or religious motive (Mohammed \& Giacomo, 2017).

\section{History of the Suroan Tradition}

The word Suro is the name for the month of Muharram in Javanese society. The word actually comes from "ashura" in Arabic which means "ten", namely the 10th of Muharram (Aryanti \& Az Zafi, 2020). The suroan tradition is a tradition practiced by the Javanese as a form of celebrating the month of Suro. What is called the Muharraman ritual (which is carried out in connection with the arrival of the month of Muharram) or the Javanese is called the suroan tradition (because it is carried out in conjunction with the month of Suro in the Javanese calendar system), is a tradition that takes the form of assimilation between Javanese culture and Islam (Solikhin, 2009).

Asyuro or Suroan day refers to the 10th day of Muharram in the Islamic calendar, in Ashuro language it comes from the word "عشش" which means " عششج" or ten. On the 10th of Muharram or Asyuro, in Islamic history, there was a very touching event for Muslims. Where there was the massacre of 72 descendants of the Prophet and his followers, which was marked by the inhuman death of Sayyidina Husein. This incident was the beginning of a series of assassinations to eradicate the Prophet 
Muhammad's family, by political Islamists, especially those of the descendants of Abu Sufyan (Aryanti \& Az Zafi, 2020).

As for the Javanese, this hijri year is used as the calendar system for Javanese Muslims, which was determined by Sultan Agung Hanyakrakusuma, who is sometimes referred to as the aboge calendar. In practice, the Islamic calendar is sometimes 1 day longer. It's just that the number of years uses Javanese, which is 78 years younger than AD. The year still uses the Saka year, but the day count is changed to a qamariyah date system. It was on the initiative of Sultan Agung that the month of Muharram became the first month of the Islamic and Javanese new year and it was from Sultan Agung that various rituals for the celebration of Muharram and Suronan were carried out and followed by all Javanese people (Safera \& Huda, 2020).

\section{Results and Discussion}

Results and discussion contain the results of research findings and discussion. Write down the findings obtained from the results of the research that has been carried out and must be supported by adequate data. Research results and findings should be able to answer the questions or research hypotheses in the introduction.

\section{Implementation of "Yatiman" Tradition in Pekalongan}

The implementation of the yatiman tradition in the month of Suro in Panjang Baru Village, RW IX Pekalongan, has its own meaning for the community. That the implementation of this yatiman tradition is expected to strengthen the relationship, between residents of Panjang Baru Village, RW IX Pekalongan. Each type of activity in the Yatiman tradition, namely:

\section{Tahlil and Prayer Together}

The implementation of the yatiman tradition, which is held from the night of 10 Suro / Muharram, ba'da Isya or around 19:00, begins with a prayer, led by ustadz Agus Siswanto. This joint prayer activity was carried out at a crossroads in Kelurahan Panjang Baru RW IX, until it filled the streets. This activity is carried out some time before the feast which is also held on the night of the suroan.

This activity was attended by RW, RT heads, religious leaders, youth leaders, orphans, and the community of Panjang Baru Village RW IX. In the implementation of 
the yatiman tradition in Kelurahan Panjang Baru RW IX, after the residents had gathered at the place of the suroan, before the feast was held a prayer reading led by Ustadz Agus Siswanto, this prayer reading was to face safety and blessings in the following year.

The activity of praying together in the yatiman tradition is a good and good activity, because this activity is a good deed that is intended to ask for forgiveness and ask for blessings which are only shown to Allah SWT (Manan \& Aslamiyah, 2020). The reading of prayers during the yatiman traditional activity in the month of Suro is to preserve the teachings of Javanese ancestors, and the prayers are intended to ask Allah SWT to be forgiven for all mistakes in the previous year (Muchlis, Iman, \& Ariyanto, 2018).

After the residents gathered, then ustadz Agus Siswanto read a prayer to give thanks for all that God has given, and to ask for safety and smoothness for the next year and be able to carry out traditional yatiman activities every suro month. The prayers that are read in this yatiman tradition are prayers asking for safety and forgiveness which are pronounced in Javanese, then continued with the recitation of sholawat, dzikir, tahlil, tahmid, prayers and requests for forgiveness for the deceased.

\section{Kenduri}

In the implementation of the yatiman tradition in Kelurahan Panjang Baru RW IX in the month of Suro, the feast is held after the prayer reading. During the Ba'da Isya, or after the prayer reading, the people of Panjang Baru Village RW IX continue the yatiman tradition by eating together or kenduri (slametan). Kenduri is a gathering to commemorate an event, subsets, and some in the form of meals. This feast activity is carried out with the aim of saying a prayer as a form of gratitude to Allah (Beti, 2019).

The people of Kelurahan Panjang Baru RW IX carry out the feast with the aim of giving thanks for what God has given and also to ask for blessings for what they get for the following year. This perception the writer finds that there is a feast in the yatiman tradition, which is aimed at realizing gratitude to Allah for all the blessings that have been given. And that the feast on the yatiman tradition in the month of Suro is carried out so that the people of Panjang Baru Village, RW IX Pekalongan, can carry out the yatiman tradition every year. 
After the recitation of the tahlil and prayers is held a feast, the first thing to do is cutting the tumpeng, then sharing it to eat together, after that, then eat snacks that have been provided by the women of Panjang Baru Village RW IX, if there is food leftover, it can be brought home back. Tumpeng is rice that is cooked and then shaped like a cone. Pucak tumpeng is given a red and white flag and underneath it is decorated with side dishes, ingkung chicken and vegetables. The cone-shaped tumpeng in the implementation of the Suroan tradition means that people in this world will be selected, which only a few can reach the top of the cone.

Pucak cone means that only a few can arrive at the true goal of life, namely meeting Allah SWT, it is like only a few grains of rice from the many rice that make up the tumpeng. This is believed based on the beliefs of Javanese ancestors. As well as ingkung is a typical term from the Javanese people which contains the meaning of the English Njungkung which means prostrate. The point is that humans immediately prostrate to Allah SWT, that is, fully worship Allah. The ingkung chicken is only made using free-range chicken, because the taste of native chicken is more delicious than chicken.

Symbolized by the chicken ingkung because humans are expected to imitate the behavior of chickens, chickens do not eat all the food they are given, but only eat good and bad foods (Arifianto, Nurman, \& Dewi, 2018). In addition, chickens are animals that are closest to society, chickens are animals that are easy to raise, and can also be used as food (Pranata \& Ikhsan, 2018). Tumpeng and ingkung are eaten together after the recitation of the Suroan feast prayer like this is carried out as a medium of tasyakuran with the hope that Allah SWT will give additional blessings to what is given for the following year.

In connection with the feast in the implementation of the Suronan tradition, according to researchers this activity aims to create unity among residents of Panjang Baru Village RW IX, to establish ties between residents, strengthen Islamic brotherhood or brotherhood between residents, because in carrying out festive activities in the yatiman tradition in the month of Suro This whole community of Kelurahan Panjang Baru RW IX who are Muslim are gathered together. As well as in the festive activity in the month of Suro, this is a place to give alms between fellow residents of Kelurahan Panjang Baru RW IX, because in this activity the people of Kelurahan Panjang Baru 
RW IX can exchange food, share the food they bring, which is the giving of each other, alms that reflect good morals.

In essence, kenduri is a social activity to foster togetherness. In the feast, all the people present are gathered into one goal. Kenduri is expected to unite, strengthen unity, and show togetherness with an atmosphere full of harmony, joking, sharing food, shaking hands, and describing the next day's activities, namely tausiyah and donations for orphans.

\section{Tausiyah}

In many areas, especially in Java, especially Kelurahan Panjang Baru RW IX, tausiyah or tabligh akbar has become a fixed menu in every agenda of Muslim activities. It can be said, there is no Islamic holiday without tausiyah. So that the committee or youth leaders of Kelurahan Panjang Baru RW IX carried out the yatiman tradition the next day, 10 Suro or Muharram at 08:00 the activity was held at the waqf house by inviting orphans.

In the orphanage activities in Panjang Baru Village, RW IX, several figures attended, namely the Head of RW and RT Head, religious leaders, youth leaders, guardians of orphans, and orphans. The tausiyah activity was led by ustadz Agus Siswanto with the delivery of tausiyah regarding the month of Muharram or the month of Suro. The da'wah delivered by Ustadz Agus Siswanto had specific materials and objectives. There are three elements of da'wah material delivered by Ustadz Rasijan, namely: explaining the meaning of the yatiman tradition activities in this month of Suro, there are Islamic educational values from aqidah, sharia, and morals. These three aspects are the most basic correspondences for Islam and its civilization and are interrelated with one another. Correct aqidah forms the basis for true sharia, and true sharih forms the basis for good and correct individual morals and social morals.

Then proceed with reading tahlil, dzikir, tahmid, then the reading of the history of the Prophet Muhammad SAW or Rawi Maulid. As well as ustadz Agus Siswanto leading year-end prayers and early year prayers which were attended by all residents present along with the orphans, a prayer that was also devoted to orphaned children. and requests for forgiveness for people who have died. Then proceed with the orphanage assistance activities. 
The purpose of holding tausiyah in the yatiman tradition in the month of Suro in Kelurahan Panjang Baru RW IX is to help people worship Allah SWT. in accordance with the Shari'a, changing the bad conditions experienced by Muslims into better and correct conditions, educating Muslim personalities with Islamic education, and preparing Muslim communities that stand on the foundations of Islamic culture and morality.

\section{Compensation for orphans}

In the implementation of the orphan tradition in Kelurahan Panjang Baru RW IX, which is a mandatory activity is to support orphans on the 10th of Muharram. This is because the people of Kelurahan Panjang Baru RW IX believe that whoever rubs the head of an orphan on the day of Ashura, Allah will guarantee his life in this world and the hereafter.

One of the activities that became the mandatory agenda at the time of implementing the suroan tradition in Kelurahan Panjang Baru RW IX was supporting orphans. In the implementation of the yatiman tradition in the month of Suro in Kelurahan Panjang Baru RW IX, every year there are always activities to support orphans, which are held in houses that are donated for religious activities, a house located in Kelurahan Panjang Baru RW IX.

This activity of supporting orphans aims to help orphaned children in Kelurahan Panjang Baru RW IX, to fulfill their daily needs and provide protection for orphaned children from children's social problems. Who will rub the head of the orphan on the day of Ashura or on the 10th of Muharram and treat him well on that day, even though he can only glorify the orphan once a year, if done sincerely, God willing, it is guaranteed by Allah in the world and the hereafter.

The implementation of activities to support orphans in the orphan tradition in the month of Suro in Kelurahan Panjang Baru RW IX starts at 08:00 until finished. This activity was preceded by remarks from the chairman of RW Panjang Baru RW IX, followed by tausiyah and prayer together led by religious leaders of Kelurahan Panjang Baru RW IX, then distribution of compensation to orphans. Each year this activity varies in the amount of compensation and the number of recipients. The amount of compensation was obtained from community donations in Panjang Baru Village, RW IX. 
The compensation given to orphans is infaq from the community of Panjang Baru Village RW IX. Every time this event will be held on the 10th of Muharram, the village head assigns an officer or committee to implement the Suroan tradition who is specifically involved in supporting orphans, a group of youths or the head of RT Kelurahan Panjang RW IX to go around in order to raise funds that are not limited in number so that all residents can contribute in this activity.

Based on the information obtained from the author's interview with the chairman of RW IX, activities to support orphans in the orphan tradition in this Suro month can also be beneficial for orphans in Kelurahan Panjang Baru RW IX, because this activity can help them to make ends meet they. For example, donations of funds collected from the local community can be used to meet food needs, provide education, and so on.

\section{Analysis of the Islamic Education Values Towards the Yatiman in Pekalongan}

Referring to the research focus previously described, this study is focused on looking at the values of Islamic education contained in the yatiman traditional activities in the month of Suro in Panjang Baru Village RW IX Pekalongan. In the aspect of Islamic education values, there are three things, namely the value of aqidah education, the value of sharia education, and the value of moral education. In connection with the yatiman tradition in the month of Suro in Panjang Baru Village RW IX, this researcher will analyze the value of aqidah, sharia, and morals education in the types of yatiman traditional activities in the month of Suro in Panjang Baru Village RW IX Pekalongan.

The implementation of the Suroan tradition has different styles and procedures in each region, as well as the implementation of the yatiman tradition in the month of Suro in Panjang Baru Village, RW IX Pekalongan. The types of yatiman traditional activities during the month of Suro in Panjang Baru Village, RW IX, are Tahlil and joint prayer, feast, tausiyah and donations for orphans.

From the data obtained based on the results of interviews with several resource persons, namely the head of Lurah Panjang Baru RW IX, the head of RW, RT, religious leaders, youth leaders, orphans and representatives of the community of Panjang Baru Village RW IX, even though they have experienced acculturation with the values Islam, however until now the implementation of the yatiman tradition in the month of Suro is 
still colored by various symbols with the Javanese style. Like the use of tumpeng and ingkung which have their own meaning for the community. Therefore, the researcher will look at the values of Islamic education in traditional Yatiman activities in the month of Suro in Panjang Baru Village, RW IX Pekalongan.

\section{The Value of Aqidah Education in the Yatiman Tradition in the Month of Suro}

The value of aqidah education in the yatiman tradition in the month of Suro can be seen in the festivity activities. As previously described, kenduri in the Suroan tradition concerns the issue of faith, namely belief that if you don't carry out this tradition, you will get bad luck. Aqidah is a belief, if you believe that the feast on the night of Suroan is an obligation which if it is not carried out will get bad luck is a deviant thing.

Think of it as unlucky because something in Islam is known as Thiyarah. In a hadith narrated by Tirmidhi which means:

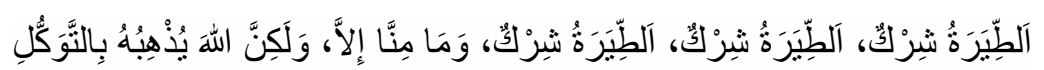

This means: "Thiyarah is shirk, thiyarah is shirk, thiyarah is shirk. And everyone must have crossed his mind (leading to thiyarah). It's just that Allah eliminates with a tawakal attitude" (HR. Tirmidzi).

In essence, think of it as time, place, month, or bad luck assuming that it is unlucky because of a certain thing is something that is forbidden, even including shirk. What should be contemplated if you are having bad luck or disaster is, we should take the wisdom that all is the will and destiny of Allah. And Allah will not just bring a disaster, there must be a reason. The reason is because of our own actions.

Since then until now all Muslims are required to have pure aqidah. However, the spiritual life of the people of Panjang Baru Village, RW IX Pekalongan, still shows their belief in their ancestors in the form of the yatiman tradition in the month of Suro. They believe that if they do not carry out the feast on the Suroan night, they will get bad luck, besides that there is also a likeness to the symbols in tumpeng and ingkung ayam.

The principle of divine teaching in Islam lies in monotheism (absolute unity of God). The tauhid formulation is confirmed in the QS. Al-Ikhlas verses 1-4 which read:

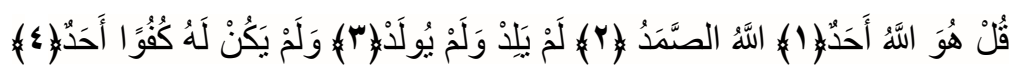


Meaning: "1). Say: He is Allah, the One and Only. 2). Allah is a God who depends on Him for everything. 3). He was neither childless nor begotten, 4). and there is no one equal to Him ".

Every person who believes must know that in everyday life there are things that have been stated in the Qur'an, including shirk, and in this tradition, people generally think that if they do not carry out this ancestral tradition they will be bad luck, and if carrying out this activity they will get blessings, safety, and avoid disaster. Whether we realize it or not, this kind of perception of society easily drags into idolatry.

In Islam, humans are required not only to have faith with believe in the pillars of faith alone, but Islam demands that faith be proven in real deeds. Meanwhile, it is the proof and realization of faith by carrying out all the instructions and commands of Allah Most High and His Messenger based on our maximum capabilities as humans, and staying away from all prohibitions.

Believing in the philosophical meaning of the previous ancestors which will get bad luck (Горячев, 2020), if you do not carry out the Suroan tradition will get bad luck, even though the reason for maintaining and preserving the beliefs of this ancestral cultural tradition is an act of shirk, so this kind of belief needs to be shunned and abandoned.

In this case, to straighten the aqidah of society, we fellow Muslims are not required and do not need to prohibit or erase existing traditions, but by giving an understanding to society that what is being done is not in accordance with Islamic aqidah and can plunge the community into shirk. Actions that are not in accordance with Islamic aqidah can be replaced with Islamic actions.

Initially, the implementation of the feast was a habit with a menu of meat, fish, liquor, and free intercourse, which was carried out naked in the field. Then, by Sunan Ampel and Sunan Bonang, Islamic values were included by changing the procedure a little, with a fixed circle position, but the dishes were replaced with tumpeng rice, chicken, fish and sweet tea drinks.

Based on the description above, it is clear that kenduri has been around for a long time but has undergone changes brought by Sunan Bonang and Sunan Ampel. In 
the tradition of suroan kenduri it is intended as alms in the form of food after praying and being grateful for the abundance of harvests and other blessings.

Kenduri is indeed allowed, it's just that the implementation of the feast in the suroan tradition is not recommended because the implementation of the feast during the implementation of the yatiman tradition in the month of Suro in Kelurahan Panjang Baru RW IX is believed to reject or avoid bad luck where this kind of belief is not in accordance with Islamic aqidah.

As Muslims who follow the Prophet Muhammad, we should respond to the month of Suro or Muharram by increasing our devotion to Allah SWT, instead of being trapped by the negative assumptions of the month of Suro as is common in society. When viewed from the point of view of aqidah education, the belief that if you don't carry out this tradition will get bad luck in this case it is not in accordance with the objectives of aqidah education, because aqidah education aims to strengthen religious aqidah and enlighten religious nature. So that now the people of Panjang Baru Village RW IX already contain the value of aqidah education in the Yatiman traditional activities in the month of Suro in festive activities that only hope for His blessing.

\section{The Value of Sharia Education in the Yatiman Tradition in the Month of Suro}

a. Value of Sharia Education in Tahlil and Prayer Activities

The value of sharia education in the yatiman tradition in the month of Suro can be found in prayer activities that have become part of the community of Panjang Baru RW IX in the implementation of the suroan tradition. In defining the activity of praying together, the writer tries to describe it in several things related to the culture of society in general regarding the mention of this activity, namely tahlilan (Librianti \& Mukarom, 2019).

Prayer together is a good thing to do because it is to get closer to God. In general, there is nothing wrong with praying together in the yatiman tradition in this suro month. In QS. Al-Ashr verses 1-3 Allah said:

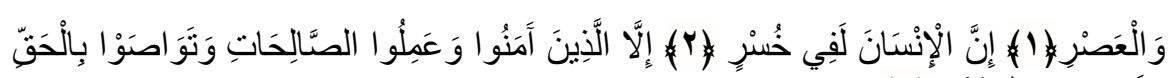

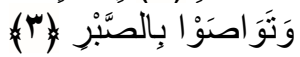

Meaning: "1) for the sake of time. 2) In fact, humans are really at a loss, 3) Except for people who believe and do good deeds and advice to adhere to the truth and advice to give patience ". 
In this verse it is explained that we must advise each other in the truth, and this joint prayer activity is a truth that does not contradict Islamic teachings. The prayer must be said at any time, wherever the place is, and whenever the time is. Prayers can be recited silently or verbally, prayers can be done individually or in groups. Do'a has many virtues, one of which is prayer can make the heart calm (Muniri, 2020).

In the activity of praying together, the people of Kelurahan Panjang Baru RW IX are intended to reflect on all the mistakes in the previous year, self-introspection is indeed very necessary, but self-reflection is not enough to do for just one night, because the longer time is used for introspection. Ourselves, surely we will be wiser in dealing with this life.

Based on the description above, the writer concludes that, from the point of view of sharia education, praying together during the implementation of the yatiman tradition in the month of Suro is a good and recommended practice.

\section{b. The Value of Sharia Education in Tausiyah Activities}

The value of Sharia education in the yatiman tradition in the month of Suro in Panjang Baru Village RW IX is found in tausiyah activities by implementing the lecture method and reading the holy verses of the Al-Qur'an through a loudspeaker. Tausyiah activities can provide insight into Islamic religious knowledge for the community. Through lectures delivered at this activity, it includes the dimensions of religious knowledge, the dimension of appreciation, and according to the process of implementing sharia values.

Tausiyah activities are important to carry out in every religious activity due to the reality that occurs in today's society, the majority of orphans lack understanding of religious education. This is because the parents who died or the parents did not fully master and understand religious principles or religious knowledge, so they could not practice them. Another factor that may cause this problem is the lack of religious education which often does not receive support from the surrounding environment (Sholehuddin, Munjin, \& Adinugraha, 2021).

This lecture strategy was used by Ustadz Agus Siswanto to provide explanations to the community regarding the values of Islamic education so that people know and understand Islamic teachings and then practice them in everyday life. Besides that, materials that are also important to be conveyed are the values of brotherhood, love and 
affection, togetherness and mutual help and so on. The values above need to be cultivated in society, considering that the community of Panjang Baru Village, RW IX, is a plural society.

\section{The Value of Moral Education in the Yatiman Tradition in the Month of Suro}

The people of Kelurahan Panjang Baru RW IX Pekalongan carry out activities for orphans in the month of Suro based on a hadith, the Prophet SAW mentioned the virtue of giving assistance to orphans in general, there is no mention of a specific time, namely:

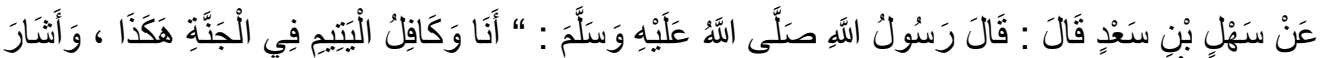

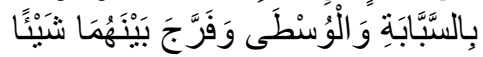

Meaning: "From sahl bin Sa'ada. Said: Rasulallah Saw said: "I and those who bear the life of the orphan like these two fingers while in heaven" then He hinted with the index finger and middle finger, and he separated them a little "(Narrated by Bukhori).

Based on the above hadith, the writer concludes that the virtue of helping orphans applies at any time and actually supporting and making orphans happy is ordered to be done at any time, not only on the 10th of Muharram. Even though the hadith that is used as motivation for the people of Panjang Baru Village RW IX to support orphans on the 10th of Muharram is not a authentic hadith, as long as this activity does not start with religion, it is permissible and okay because it is a value of local wisdom. This is in accordance with the objectives of sharia education, namely to expand knowledge about Islamic laws (Adinugraha, 2018).

Researchers also found the value of moral education in one of the mandatory activities of the community in Panjang Baru Village RW IX when carrying out the orphan tradition in the month of Suro, namely activities to support orphans. With the activities of supporting orphans during the month of Suro, the orphans in Panjang Baru Village RW IX can feel happiness on that day. All their needs are met from the donations collected from the community of Panjang Baru Village, RW IX. Some of the benefits obtained are used for circumcision, eating together in full togetherness, this activity can also eliminate distrust between orphans in Panjang Baru Village RW IX. This activity can make them feel the same way as children who still have complete parents. 
Although actually in Islam, donating to orphans is not limited to the month of Suro, and in practice the activity of the orphan tradition in this month of Suro does not find a clear source, but the author believes this activity is good rather than never doing good to orphans at all. Even though it is a part of the honor in supporting orphans, there is no specific information regarding the implementation in what month. It is undeniable that child sponsorship is a form of noble deeds, but if you believe by rubbing the head of an orphan on the 10th of Muharram, Allah will guarantee that the world and the hereafter is a wrong perception. The virtue of helping orphans applies at any time, anytime and there is no special time.

The community of Panjang Baru Village, RW IX Pekalongan, carried out in the month of Suro because it was the most common activity among the community. Suronants can symbolize the social unity of the people who participate in these activities. If seen from the point of view of akhak education. Suronan can develop unity, harmony, prosperity, and prosperity for the people of Kelurahan Panjang Baru RW IX who participate in these activities, without any quarrels and mutual respect.

Suroan in the yatiman tradition is still being carried out and preserved until now because it is expected to be able to connect the relationship and strengthen Islamic brotherhood among the people of Panjang Baru Village RW IX. The community also looks happy when participating in this traditional festivals, this can be seen in the atmosphere full of jokes between them.

When viewed from the point of view of moral education, the researchers concluded that, in essence, suronan is a social activity to care for and maintain togetherness so that the kenduri activity is added in it. Kenduri is able to unite, even more, to strengthen the unity between the community and each individual involved in it. In the feast, the value of moral education is seen in an atmosphere full of harmony, jokes between one another, sharing of food eaten together or when shaking hands (Anas \& Adinugraha, 2017). Yatiman traditional activities in the month of Suro are norms / rules that have been passed down from generation to generation. In this regard, there is one of the morals towards society, namely respecting the values and norms that apply in all forms of mutual interest.

So it can be concluded, activities to support orphans during the implementation of the suroan tradition are actually wrong because the most important thing is not to 
hope for a life guaranteed by God in the world and the hereafter just because we glorify orphans at one time, but it should be our intention to help and ease their burdens. However, activities to support orphans during the implementation of the orphan tradition in the month of Suro are good activities from the point of view of moral education, with a note of our intentions to help, ease the burden, and make them happy.

\section{Conclusion}

Based on the results of research, it can be concluded that new finding of this research is the implementation of the yatiman tradition in the month of Suro in Kelurahan Panjang Baru RW IX Pekalongan, the community gathered together activities that began with Talil, joint prayer, and feasts at 10 Suro or Muharram. Then the next day, the activities continued with tausiyah and donations for orphans. The values of Islamic education that are found in the yatiman tradition in the month of Suro are the values of sharia education in tahlil, joint prayer, and tausiyah activities. Meanwhile, the implication is that the value of moral education found in all activities in the yatiman tradition in this month of Suro is in accordance with the purpose of moral education, namely to practice good behavior, both with others, nature, and God. While the values of Islamic education, in the value of faith are found in the yatiman tradition activities in the month of Suro in Panjang Baru Village RW IX Pekalongan, there is a mismatch between Islamic aqidah and the beliefs of the ancestors that are believed by the community, that is if you do not carry out this tradition, you will get a bad luck. This is not in accordance with the purpose of aqidah education, where aqidah education aims to strengthen aqidah together and enlighten religious nature. However, now the people of Kelurahan Panjang Baru RW IX have turned it into aqidah value, which is a matter that must be believed to be true by the heart, soothes the soul, and becomes a belief that is not mixed with doubt.

\section{BIBLIOGRAPHY}

Abidin, Z. (2019). Makna Tradisi Suran (Kegiatan Malam Satu Sura) dalam Menjalin Ukhuwah Islamiyah di Desa Sriwijaya Mataram Kecamatan Bandar Mataram Kabupaten Lampung Tengah. Skripsi Fakultas Dakwah Dan Ilmu Komunikasi Universitas Islam Negeri (UIN) Raden Intan Lampung, (3), 1-129.

Adinugraha, H. H. (2018). Kearifan Lokal di Pedesaan: Kajian Praktik Budaya Religi Di Desa Nyatnyono. International Journal Ihya' 'Ulum al-Din, 20(1). 
https://doi.org/10.21580/ihya.20.1.2997

Adinugraha, H. H., Hasan, A., Pekalongan, I., \& Semarang, U. I. N. W. (2020). Understanding of Islamic Studies Through Textual and Contextual Approaches, $17(1), 26-48$.

Ahmad Jamalong, Sukino, S. (2019). Pendidikan Pancasila dan Kewarganegaraan di Perguruan Tinggi. American Journal of Epidemiology (Vol. 183).

Ahmadi, A. (2020). Ilmu Pendidikan Islam Sebagai Perspektif Kehidupan. AL-FIKR: Jurnal Pendidikan Islam, 5(2). https://doi.org/10.32489/alfikr.v5i2.27

Anam, S., Degeng, I. N. S., Murtadho, N., \& Kuswandi, D. (2019). The moral education and internalization of humanitarian values in pesantren. Journal for the Education of Gifted Young Scientists, 7(4). https://doi.org/10.17478/jegys.629726

Anas, A., \& Adinugraha, H. H. (2017). Dakwah Nabi Muhammad terhadap Masyarakat Madinah Perspektif Komunikasi Antarbudaya. Ilmu Dakwah: Academic Journal for Homiletic Studies, 11(1), 53-72. https://doi.org/10.15575/idajhs.v11i1.1356

Anggito, A. dan J. S. (2018). Metodologi Penelitian Kualitatif. Sukabumi: CV. Jejak.

Arifianto, D., Nurman, N., \& Dewi, S. F. (2018). Nilai-Nilai Moral dan Sosial dalam Penyelenggaraan Kenduri Sudah Tuai di Desa Kumun Mudik Kota Sungai Penuh. Journal of Civic Education, 1(3). https://doi.org/10.24036/jce.v1i3.213

Aryanti, R., \& Az Zafi, A. (2020). Tradisi Satu Suro Di Tanah Jawa Dalam Perspektif Hukum Islam. AL IMAN: Jurnal Keislaman dan Kemasyarakatan, 4(2).

Ayuningsih, W., Syafaruddin, S., \& MS, A. (2020). Implementation of Islamic Education Curriculum Development in Al-Ulum Islamic School Medan. Budapest International Research and Critics in Linguistics and Education (BirLE) Journal, 3(2). https://doi.org/10.33258/birle.v3i2.1031

Beti, L. A. (2019). Budaya Kenduri Sebagai Sedekah di Desa Parelor Kecamatan Kunjang Kabupaten Kediri. Artikel Jurnal, 8(5).

Darmadi, H. (2019). Dasar Konsep Pendidikan Moral. Bandung: Alfabet.

Eakman, A. M. (2015). The meaningful activity wants and needs assessment: A perspective on life balance. Journal of Occupational Science, 22(2). https://doi.org/10.1080/14427591.2013.769405

Filson, C. P. (2018). Quality of care and economic considerations of active surveillance of men with prostate cancer. Translational Andrology and Urology. https://doi.org/10.21037/tau.2017.08.08

Frensch, P. A., \& Funke, J. (1995). Definitions, traditions, and a general framework for understanding complex problem solving. Complex problem solving The European perspective.

Halik, A. (2020). Ilmu pendidikan islam: perspektif ontologi, epistemologi, aksiologi. Istiqra', 7(2).

Huda, M. (2015). Hasan Al-Banna Thought Actualisation In The Islamic Education Development. QIJIS: Qudus International Journal of Islamic Studies, 3(1).

Isdiana. (2017). Tradisi Upacara Satu Suro dalam Perspektif Islam (Study di Desa 
Keroy Kecamatan Sukabumi Bandar Lampung). UIN Raden Intan Lampung, 12(1).

Janah, U. R. (2016). Nilai-Nilai Filantropi Pada Tradisi Yatiman di Brotonegaran Ponorogo. kodifikasi, 10(01).

Kartono, K. (1983). Pengantar Metodologi Reserach Sosial. Bandung: Alimini.

Librianti, E. O. I., \& Mukarom, Z. (2019). Budaya Tahlilan sebagai Media Dakwah. Prophetica: Scientific and Research Journal of Islamic Communication and Broadcasting, 5(1). https://doi.org/10.15575/prophetica.v5i1.1306

Lubis, S. A., Neliwati, \& Ficki Padli Pardede. (2020). The Implementation of Akhlaq Education Values in Academic Services at STIT Al Hikmah Tebing Tebinggi. International Journal for Educational and Vocational Studies, 2(11).

Lubis, Z., \& Anggraeni, D. (2019). Paradigma Pendidikan Agama Islam di Era Globalisasi Menuju Pendidik Profesional. Jurnal Online Studi Al-Qur'an, 15(1). https://doi.org/10.21009/jsq.015.1.07

Mahmuda, M. (2019). Anak Yatim Sebagai Objek Dakwah dalam Perspektif Al-Qur'an. Al-Hikmah: Jurnal Dakwah dan Ilmu Komunikasi, 1(2). https://doi.org/10.15548/al-hikmah.v1i2.111

Manan, A., \& Aslamiyah, S. S. (2020). Implementasi Budaya Religius dalam Perkembangan Moral Peserta Didik. Akademika, 13(01). https://doi.org/10.30736/adk.v13i01.140

Martin, J. L., \& Lembo, A. (2020). On the other side of values. American Journal of Sociology, 126(1). https://doi.org/10.1086/709778

Mohammed, A. S., \& Giacomo, S. (2017). A survey on species diversity, abundance and community structure of woody plants in burial sites in Gobeya Rural Administrative of Tehuledere District, South Wollo, Ethiopia. Journal of Ecology and The Natural Environment, 9(4). https://doi.org/10.5897/jene2017.0634

Muchlis, M. A., Iman, N., \& Ariyanto, A. (2018). Peran Pendidikan Kepramukaan dalam Membangun Jiwa Kepemimpinan Peserta Didik di MA Sulamul Huda Siwalan Mlarak Ponorogo. TARBAWI:Journal on Islamic Education, 2(01). https://doi.org/10.24269/tarbawi.v2i01.248

Muniri, A. (2020). Tradisi Slametan: Yasinan Manifestasi Nilai Sosial-Keagamaan di Trenggalekstasi Nilai Sosial-Keagamaan di Trenggalek. J-PIPS (Jurnal Pendidikan Ilmu Pengetahuan Sosial), https://doi.org/10.18860/jpips.v6i2.9050

Muqoyyidin, A. W. (2016). Internalisasi dan Akulturasi Nilai-Nilai Keislaman dalam Tradisi dan Budaya Masyarakat Jawa. Humanika, 1(2).

Nur, rofiqoh wahyu. (2016). Peranan Agama ada Tradisi Adat Suronan terhadap Pembentukan Sikap Keagamaan Remaja di Suroloyo Dusun Keceme Desa Gerbosari Kecamatan Samigaluh Kabupaten Kulonprogo DIY 2015. 147.

Pranata, L., \& Ikhsan, R. (2018). Ritual Tari Tauh dalam Kenduri Sko ( Studi 
Interpretivisme Simbolik: Masyarakat Desa Lolo Hilir ). Sejarah dan Budaya, 12(1).

Purwati, Y., \& Devi, A. D. (2020). Konsep penalaran bayani, irfani dan burhani pada pembelajaran aqidah ahlak dalam pendidikan islam. MADROSATUNA : Jurnal Pendidikan Guru Madrasah Ibtidaiyah, 3(2). https://doi.org/10.47971/mjpgmi.v3i2.275

Quadir, B., Chen, N. S., \& Isaias, P. (2020). Analyzing the educational goals, problems and techniques used in educational big data research from 2010 to 2018. Interactive Learning Environments. https://doi.org/10.1080/10494820.2020.1712427

Safera, D., \& Huda, M. C. (2020). Tradisi Suroan sebagai Tapak Tilas Walisongo (Studi di Desa Jatirejo Kecamatan Suruh Kabupaten Semarang). Al-Mada: Jurnal Agama, Sosial, dan Budaya, 3(1). https://doi.org/10.31538/almada.v3i1.500

Salman Irag Al-Najaf, F. A., Salehi, M., \& Nimr Al-Maliki, H. S. (2018). The effect of Islamic sacred months on stock prices in Iran and Iraq Stock Exchanges. ISRA International Journal of Islamic Finance, 10(1). https://doi.org/10.1108/IJIF-102017-0034

Satibi, I. (2008). Ritual Munjung Dan Bongkar Bumi Dalam Masyarakat Suku Sunda. Jakarta: Istiqroq'.

Sholehuddin, M. S., Munjin, M., \& Adinugraha, H. H. (2021). Islamic Tradition and Religious Culture in Halal Tourism: Empirical Evidence from Indonesia. IBDA `: Jurnal Kajian Islam dan Budaya, 19(1). https://doi.org/10.24090/ibda.v19i1.4470

Sholihah, A. M., \& Maulida, W. Z. (2020). Pendidikan Islam sebagai Fondasi Pendidikan Karakter. QALAMUNA: Jurnal Pendidikan, Sosial, dan Agama, 12(01). https://doi.org/10.37680/qalamuna.v12i01.214

Solikhin, M. (2009). Misteri Bulan Suro Perspektif Islam Jawa. Jakarta: Narasi.

Suharto, T. (2018). Transnational Islamic education in Indonesia: an ideological perspective. Contemporary Islam, 12(2). https://doi.org/10.1007/s11562-017-04093

Sulaiman, Yusnaini, S., Jabaliah, Masrizal, \& Syabuddin. (2020). Implementation of qanun islamic education as local wisdom based on aliyah's curriculum. Utopia y Praxis Latinoamericana, 25(Extra 2). https://doi.org/10.5281/zenodo.3808679

Supriatna, R. (2019). Model Pembelajaran Beyond Center and Circle Time (Bcct) Berbasis Q.S Lukman Ayat 12-19. Tawazun: Jurnal Pendidikan Islam, 11(2). https://doi.org/10.32832/tawazun.v11i2.1663

Suradi, A., Tabata, M. C., \& Surahman, B. (2020). The History And Values of Tolerance In Tabot Traditional Ceremonies In Bengkulu Society. Paramita: Historical Studies Journal, 30(2). https://doi.org/10.15294/paramita.v30i2.21403

Suraya, A., Hermawan, H., \& Pekalongan, I. (2020). Progressive Education in Indonesia : Insight from Soedjatmoko Thought, 7(2), 113-121. https://doi.org/10.32923/tarbawy.v7i2.1410

Susanto, H. (2018). Pembaharuan Pemikiran Islam dan Relevansinya bagi 
Pengembangan Pendidikan di Indonesia. Istawa: Jurnal Pendidikan Islam, 3(1). https://doi.org/10.24269/ijpi.v3i1.1002

Susiyani, A. S. (2017). Manajemen Boarding School dan Relevansinya dengan Tujuan Pendidikan Islam di Muhammadiyah Boarding School (MBS) Yogyakarta. Jurnal Pendidikan Madrasah, 2(2). https://doi.org/10.14421/jpm.2017.22-08

Ufie, A. (2014). Mengintegrasikan Nilai-Nilai Multikulturalisme Berbasis Kearifan Lokal Sebagai Sumber Pembelajaran Sejarah. Jurnal Criksetra.

Wiediharto, V. T., Ruja, I. N., \& Purnomo, A. (2020). Nilai-Nilai Kearifan Lokal Tradisi Suran. Diakronika, 20(1). https://doi.org/10.24036/diakronika/vol20iss $1 / 122$

Yatiman, Y., SM, A. E., \& Narti, S. (2019). Nilai Kerukunan dan Kekeluargaan Etnis Jawa dalam Tradisi Among-Among (Studi Pada Etnis Jawa di Desa Magelang Kecamatan Kerkap Kabupaten Bengkulu Utara). Profesional: Jurnal Komunikasi dan Administrasi Publik, 5(1). https://doi.org/10.37676/professional.v5i1.710

Yudha, A. T. R. C. (2016). Manajemen Pelayanan Pemberdayaan Anak Yatim pada Lembaga Amil Zakat Yatim Mandiri di Surabaya. Al Tijarah, 2(1). https://doi.org/10.21111/tijarah.v2i1.667

Горячев, Д. (2020). The Symbolism of P. Florensky and the Historicism of A. Schmemann as the Antinomy of the Believing Mind and Reasonable Faith. Theological Herald, (2(37)). https://doi.org/10.31802/2500-1450-2020-37-2-91106 